\title{
MICROFIBRIL ANGLE OF Eucalyptus grandis WOOD IN RELATION TO THE CAMBIAL AGE
}

\author{
José Tarcísio Lima ${ }^{1, \bullet}$, Alessandra de Oliveira Ribeiro ${ }^{1}$, Carolina Rezende Pinto Narciso ${ }^{1}$
}

\begin{abstract}
The microfibril angle (MFA) of wood is an important feature, which helps to explain the physical and mechanical behaviour of wood in use. It has been little investigated for wood produced in Brazil, mainly for mature trees. Thus, the objective of this study was to analyze the MFA of Eucalyptus grandis at age 25 years in relation to the cambial age. One disk was cut from the base of the stem from each of three trees, where growth rings were marked. From a central strip $3,0 \mathrm{~cm}$ wide, $1 \mathrm{~cm}^{3}$ blocks were removed from each growth ring. After sectioned on the tangential face with a sliding microtome, sections of $8 \mu \mathrm{m}$ thick were macerated. The individual fibres were observed by polarized light microscopy for measurement of $M F A$. According to the results, i) the $M F A$ decreased from $29,3^{\circ}$ (ring $\mathrm{n}^{\circ} 1$ ) to $18,9^{\circ}$ (ring $\left.\mathrm{n}^{\circ} 25\right)$; ii) MFA can be estimated by the cambial age $-a$, according to the equation $M F A=28,1-0,35 \times a$, with $\mathrm{R}^{2}=94,7 \%$.
\end{abstract}

Keywords: Cambial age, Eucalyptus grandis, microfibril angle.

\section{INTRODUCTION}

Wood is a complex biological material making it variable. The ultrastructural properties of wood, as well as other properties vary significantly between species, between trees of the same species and between different positions within the same stem, which is influenced, on the one hand, by genetic factors, and secondly, by environmental factors (Donaldson 2008).

The cellulose microfibrils are fundamental units of the cell walls of plants. In the layers of the secondary wall in wood fibres, they form angles with the fibre axis, which is called the microfibril angle (MFA).

Knowing the microfibril angle of libriform fibres of Eucalyptus wood is important for a better understanding of its behaviour. It has been reported that MFA influences the dimensional stability, rigidity and mechanical strength of woods (Barnett and Bonham 2004, Chauhan et al. 2006).

Several researchers, such as Wimmer et al. (2002), stated that the orientation of the microfibrils in the S2 layer determines, in large part, the mechanical properties of the individual fibres, as well as the properties of solid wood. As examples of these influences, strength can be affected by microfibril angle in that smaller angles are responsible for higher resistance to compression (Mott et al. 2002, Lima et al. 2004), while larger angles are responsible for greater elasticity (Barnett and Bonham 2004, Chauhan et al. 2006, Donaldson 2008).

\footnotetext{
Science and Technology of Wood, Department of forest sciences, Federal University of Lavras, Campus Universitário, 037,37200-000, Lavras-MG. Brazil

^Corresponding author: jtlima@dcf.ufla.br

Received: 21.12.2012 Accepted: 31.01.2014
} 
According to Hein and Lima (2012) MFA was found to be important in determining the mechanical behaviour of wood and appears to be a useful parameter to indicate wood stiffness and strength in juvenile Eucalyptus from short-rotation plantations. The wood properties of shrinkage and swelling are also affected by this change (Meylan and Probine 1969). The characteristics of cellulose pulps are related to MFA (Downes et al. 2003). Environmental conditions play an important role in defining the microfibril angle (Hori et al. 2002, Wimmer et al. 2002, Lima et al. 2004, Melo 2004).

For fast-growing wood planted MFA has been evaluated primarily in wood from young trees. Among the few published papers data for MFA of Eucalyptus clonal wood for the production of pulp has been described by Lima et al. (2004), Melo (2004) and Hein et al. (2012). In these studies the MFA ranged from $12^{\circ}$ to $21^{\circ}$, depending on the location and the genetic material considered. Information about the MFA for mature Eucalyptus wood is scarcely found in the literature. Even so, Ramos et al. (2011) found for 23 years old Eucalyptus grandis that MFA generally decreases with increasing cambial age.

The objective of this study was to evaluate the behaviour of microfibril angle in Eucalyptus grandis wood, aged 25 years, in relation to cambial age.

\section{MATERIAL AND METHODS}

\section{Area of sampling}

For the present study we used wood from three trees of Eucalyptus grandis, aged 25 years, from existing planting on the farm of the Federal University of Lavras, Minas Gerais State, Brazil, situated at an average altitude of $914 \mathrm{~m}$, at geographic coordinates $\left(21^{\circ} 14^{\prime} 30^{\prime \prime} \mathrm{S} 45^{\circ} 00^{\prime} 10^{\prime \prime} \mathrm{W}\right)$. The climate is classified as Cwa for humid temperate climate with dry winter and hot summer, according to the criteria proposed by Köppen (1931). The average annual temperature varies around $19.3^{\circ} \mathrm{C}$ and average annual rainfall around $1530 \mathrm{~mm}$, with an annual humidity of $76 \%$. The three trees were cut near the base. From this position a $3 \mathrm{~cm}$ thick disk was collected.

\section{Sample preparation}

The wooden disks were sanded for better visualization of the growth rings, which were scored from 1 to 25 from pith to bark. From each disk a $3 \mathrm{~cm}$ wide diametric strip was cut from each individual opposite side $\mathrm{A}$ and side $\mathrm{B}$ (Figure 1).

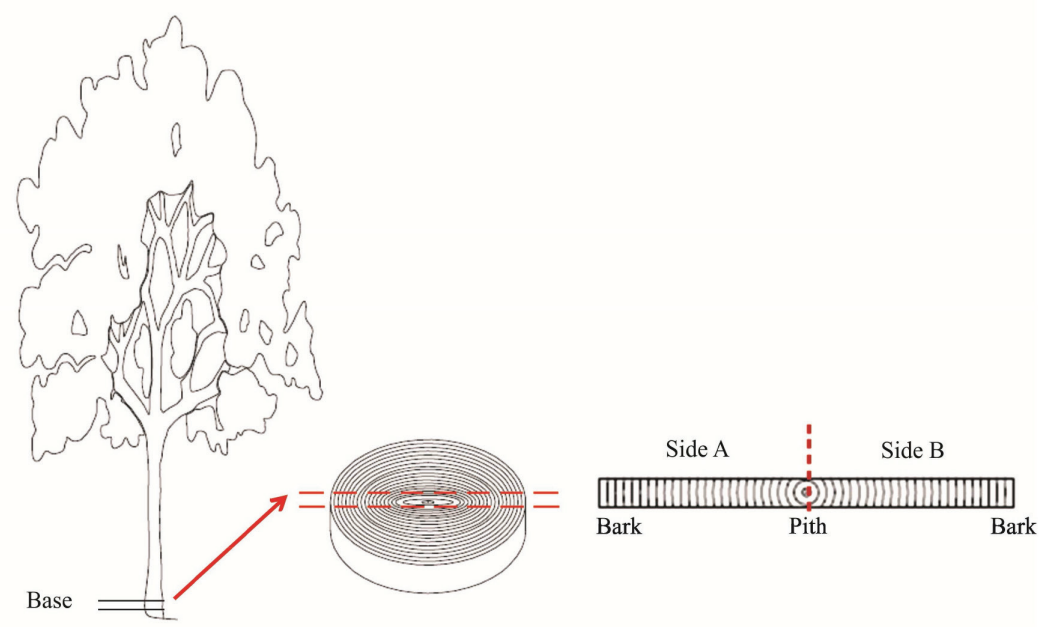

Figure 1. Removal of samples for analysis of the microfibril angle. 
Blocks were removed $(1 \times 1 \mathrm{~cm})$ for each ring with the aid of a chisel. The blocks were saturated in water and sectioned tangentially into sections of $8 \mu \mathrm{m}$ thickness using a sliding microtome. This thinner thickness of the sections were adopted to follow recommendation by Leney (1981) who emphasizes the need to use fibres cut in half longitudinally (half-fibres). This technique is based on recommendations made by Preston (1974), whereby the tilted axes of the crystals of the microfibrils from two opposite faces of a round entire fiber overlap, preventing the measurement of MFA.

According to the method adopted by Leney (1981), the sections were placed in a solution of glacial acetic acid and hydrogen peroxide 35 volumes in the volumetric proportion of 1:1 for dissociation of cellular elements for 24 hours in an oven at $60^{\circ} \mathrm{C}$. Subsequently, when the mass of sections became bleached, they were washed in distilled water and temporary slides prepared for measuring the microfibril angle.

MFA was measured using the technique of polarized light microscopy, proposed by Preston (1974) using a Olympus BX51 microscope, equipped with a rotary stage graduated from $0^{\circ}$ to $360^{\circ}$. The fibres were so positioned as to stay upright. Then the table was rotated until the sample reached the maximum extinction position, that is, the background colour of the fibre became darker, thus noting the angle presented. Thirty measurements were performed by sampled position.

The microfibril angle value was regarded as the average of the measured angles in fibres from the rings on both sides of the three trees.

\section{RESULTS AND DISCUSSION}

The mean MFA of Eucalyptus grandis wood was 23,5 (Table 1). Boyd (1985) reports that generally, the orientation of the microfibrils in the S2 layer in angiosperms (including Eucalyptus) ranges from $5^{\circ}$ to $20^{\circ}$. In turn, Bailleres et al. (1995) investigating MFA of hybrid clones of Eucalyptus wood, aged 31, 82, 105 and 142 months, found values between $0^{\circ}$ and $27^{\circ}$, with an average of $9,5^{\circ}$. Melo et al. (2004) studying the influence of topography on the MFA in 4 two-year old E. grandis $\times E$. urophylla clones, found that the overall average was $26^{\circ}$. Lima et al. (2004) found an average angle of $8,8^{\circ}$ for wood of clones of Eucalyptus grandis $\times$ Eucalyptus urophylla at eight years of age.

Hein et al. (2012) found an average MFA equal to $10,3^{\circ}$ for wood of 30 clones of six-year-old Eucalyptus grandis $\times$ E. uroplhylla, planted for pulp production. In this work, the MFA was predicted by measuring the spectrum of near infrared radiation emitted by the wood samples (independent variable) correlated with the MFA predicted by X-ray diffraction. MFA values have been obtained in a number of studies of angiosperms (including Eucalyptus) and considerable variation was found even in the same genus. Factors such as species, environment, age or even the experimental method used to measure the angle may be leading to different results. For example, Donaldson (2008) in a review of the literature found on the MFA angles ranging from $0^{\circ}$ to $40^{\circ}$, depending on the species and sampling position in the stem, both longitudinal and radially. Stuart and Evans (1995) report that MFA of Eucalyptus nitens decreases from pith to bark and is smaller for latewood than earlywood. Lima et al. (2004) concluded that environmental stresses play an important role in defining the MFA of wood of 11 clones of Eucalyptus, planted in four different sites. They found that the MFA changed statistically depending on the considered site. However, the exact information over the MFA depends on the employed method for the measurement as reported by Barnett and Bonham (2004). They concluded that "of the many techniques that have been applied for the measurement of MFA, methods involving X-ray diffraction are probably the most reliable".

In the present study, small differences were found between the three trees. Mean MFA determined between 25 growth rings per tree were $23,0^{\circ}, 23,1^{\circ}$ and $24,3^{\circ}$. Cown et al. (1999) found that there is a tendency for MFA to exhibit less variation among trees in mature timber over 15 years of age than in juvenile wood, 
which is one reason for the MFA to be a significant factor in the mechanical properties of wood including stiffness. However, Evans et al. (2000) reported that there is a difference in the variation of MFA in species of angiosperms between trees, this variation being greater near the pith in E. nitens at 15 years of age.

According to Figure 2 it can be seen a gradual reduction of MFA from the first year of age toward the $25^{\text {th }}$ year on both sides of the disk.

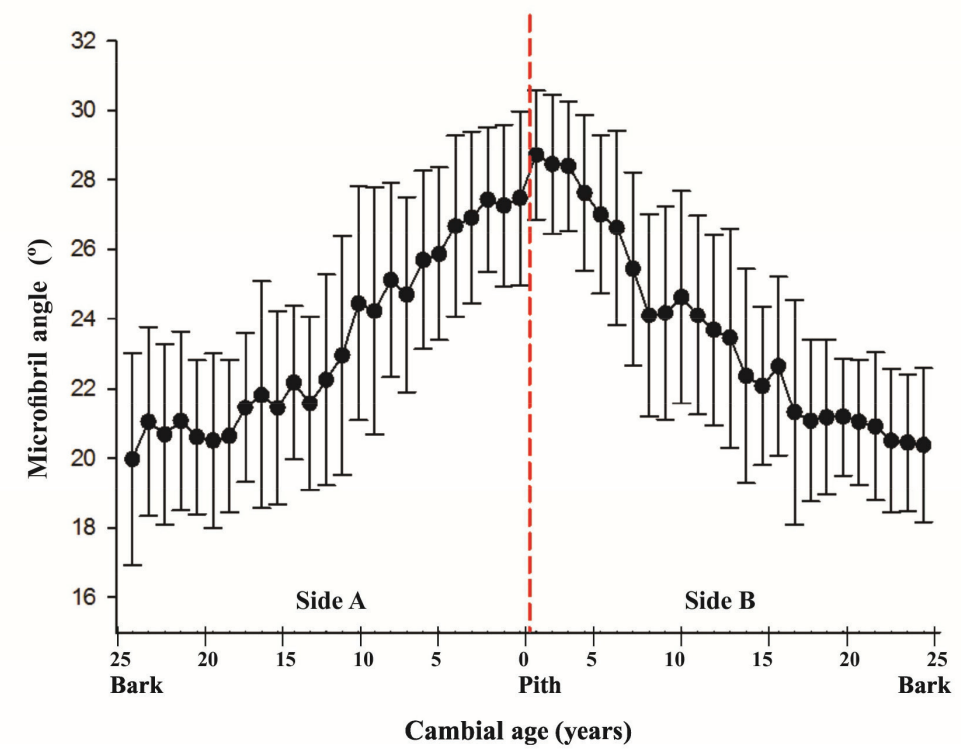

Figure 2. Variation of the microfibril angle in Eucalyptus grandis wood according to the cambial age of the stem.

MFA on side A varied from $18,7^{\circ}$ to $28,6^{\circ}$, while the side B such variation was $19,2^{\circ}$ to $30,1^{\circ}$ (Table 1 ). The average microfibrillar angle on side A was $\left(23,4^{\circ}\right)$ and side $\mathrm{B}\left(23,7^{\circ}\right)$. The fact that averages of the A and $\mathrm{B}$ sides of the disks have presented values that are very similar can be justified by the absence of pith eccentricity in the disks, which would indicate the formation of reaction wood. It is known that the MFA of the reaction wood is lower. Simpson and Tenwolde (1999) reported that the formation of this $128 \mathrm{~s}$ type of wood is often associated with stem inclination or tortuosity.

Table 1. Microfibril angle of the A and B sides in Eucalyptus grandis wood (average, maximum, minimum and coefficient of variation - CV).

\begin{tabular}{ccccc}
\hline Side & Average & Minimum & Maximum & CV \\
\hline $\mathrm{A}$ & $23,4^{\circ}$ & $18,7^{\circ}$ & $28,6^{\circ}$ & $12,07 \%$ \\
$\mathrm{~B}$ & $23,7^{\circ}$ & $19,2^{\circ}$ & $30,1^{\circ}$ & $12,12 \%$ \\
\hline Overall average & $23,55^{\circ}$ & $18,95^{\circ}$ & $29,35^{\circ}$ & $12,10 \%$ \\
\hline
\end{tabular}


It can be observed in Figure 3 that the MFA decreases from pith to bark, ie, the angles are larger for the first three growth rings with an average of $28,0^{\circ}, 27,7^{\circ}$ and $27,9^{\circ}$ respectively, while the smallest angle was $20,2^{\circ}$ in the region near the bark (ring \# 25). These results represent a linear reduction of $1,26 \%$ in MFA by growth ring, and in general there was a decrease of $31,5 \%$ in MFA from pith to bark. The estimation of MFA by the cambial age can be represented by a linear model: $M F A=28,1-0,35 \times a$, with $\mathrm{R}^{2}=94,7 \%$. This result indicates that the MFA has a high dependence on the cambial age (Figure 3).

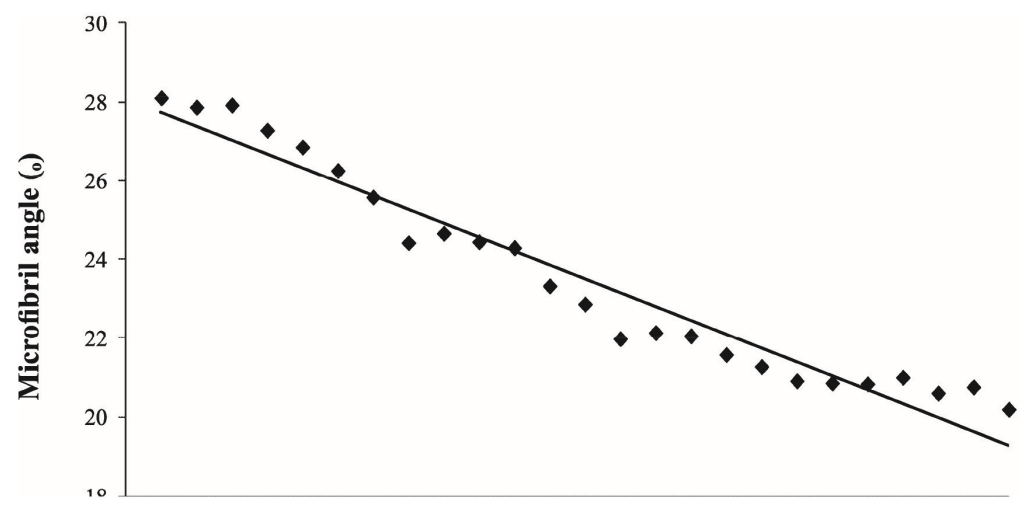

Figure 3. Estimation of the microfibril angle (MFA) of Eucalyptus grandis wood by the cambial age $\left[\mathrm{MFA}=28,1-0,35 \times \mathbf{a} ; \mathrm{R}^{2}=94,7 \%\right]$.

Stuart and Evans 1995, Lima et al. 2004, Ramos et al. 2011, Medhurst 2012, working with Eucalyptus wood, confirm that MFA reduces with the cambial age, ie, the angle is typically larger in the region of juvenile wood, near the core. Stuart and Evans (1995) studying E. nitens found angles from $10^{\circ}$ to $20^{\circ}$, decreasing from pith to cambium. Lima et al. (2004) working with Eucalyptus clones eight years of age observed a decline in the MFA from pith to bark $\left(9,6^{\circ}\right.$ to $\left.8,5^{\circ}\right)$, with an overall reduction of $13 \%$. Ramos et al. (2011) highlighted differences in the value of MFA in 23 year old Eucalyptus grandis from pith $\left(30,24^{\circ}\right)$ to bark $\left(23,79^{\circ}\right)$, which means a total reduction of $21 \%$ in the angle or approximately $1 \%$ per year. Medhurst (2012) mentions that in Eucalyptus nitens MFA decreases rapidly during the first six rings of growth, ranging from $20^{\circ}$ near the pith to $15^{\circ}$ near the bark.

According to Waghorn (2006) variation in MFA has a functional purpose in the growth and is dependent on the age of the tree, since in adult trees smaller angles result in higher stiffness of the stem so that the tree can support the weight increase of the stem and crown. 


\section{CONCLUSIONS}

The average microfibril angle of Eucalyptus grandis wood, with 25 years of age was $23,5^{\circ}$. There was a gradual decrease in the MFA with cambial age.

$M F A$ can be estimated by the cambial age (a) according to the equation $M F A=28,1-0,35 \times a$, with $\mathrm{R}^{2}$ $=94,7 \%$.

\section{ACKNOWLEDGMENTS}

Thanks to CNPq for the financial support (Contract 483293/2009-1) and scholarship. 


\section{REFERENCES}

Baillères, H.; Chanson, B.; Fournier, M.; Tollier, M.T.; Monties, B. 1995. Wood structure, chemical composition and growth strains in Eucalyptus clones. Ann Sci For 51:157-172.

Barnett, J.R.; Bonham, V.A. 2004. Cellulose microfibril angle in the cell wall of wood fibres. Biological Reviews 79: 461-472.

Boyd, J. D. 1985. Biophysical control of microfibril orientation in plant cell walls: aquatic and terrestrial plants including trees. M. Nijhoff/W. Junk, Hingham, Massachusetts, USA.

Chauhan, S.; Donnelly, R.; Huang, C.L.; Nakada, R.; Yafang, Y.; Walker, J. 2006. Wood quality: multifaceted opportunities. In: Primary wood processing: principles and practice. Walker $J$ Trees (ed) 2 nd edn. Springer, Dordrecht, pp. 159-202.

Cown, D.J.; Hebert, J.; Ball, R. 1999. Modelling Pinus radiata lumber characteristics. Part 1: Mechanical properties of small clears. NZ J For Sci 29: 203- 213.

Donaldson, L. 2008. Microfibril angle: measurement, variation and relationship - a review. IAWA Journal 29: 387-396.

Downes, G.; Evans, R.; Wimmer, R.; French, J.; Farrington, A.; Lock, P. 2003. Wood, pulp and handsheet relationships in plantation grown Eucalyptus globulus. Appita J 56: 221-228.

Evans, R.; Stringer, S.; Kibblewhite, R.P. 2000. Variation of microfibril angle, density and fibre orientation in twenty-nine Eucalyptus nitens trees. Appita J 53: 450-457.

Hein, P.R.G.; Lima, J. T.; Trugilho, P. F.; Chaix, G. 2012. Estimativa do ângulo microfibrilar em madeira de Eucalyptus urophylla $\times$ Eucalyptus grandis por meio da espectroscopia no infravermelho próximo. Revista Floresta e Ambiente 19: 194-199.

Hein, P. R.G.; Lima, J.T. 2012. Relationships between microfibril angle, modulus of elasticity and compressive strength in Eucalyptus wood. Maderas. Ciencia y tecnología 14: 267-274.

Hori, R.; Müller, M.; Watanabe, U.; Lichtenegger, H.C.; Fratzl, P.; Sugiyama, J. 2002. The importance of seasonal differences in the cellulose microfibril angle in softwoods in determining acoustic properties. $J$ Mat Sci 37: 4279-4284.

Köppen, W. 1931. Grundriss der Klimakunde: Outline of climate science. Berlin: Walter de Gruyter. 388 p.

Leney, L. 1981. A technique for measuring fibril angle using polarized light. Wood and Fiber 13: 13-16.

Lima, J.T.; Breese, M.C.; Cahalan, C.M. 2004. Variation in microfibril angle in Eucalyptus clones. Holzforshung 16: 160-166.

Medhurst, J.; Downes, G.; Ottenschlaeger, M.; Harwood, C.; Evans, R.; Beadle, C. 2012. Intraspecific competition and the radial development of Wood density, microfibril angle and modulus of elasticity. Trees 26: 1771-1780.

Melo, V.M. 2004. Variações nas propriedades da madeira de clones de Eucalyptus cultivados em diferentes topografias e sujeitos a tempestades. M.S. Thesis, Universidade Federal de Lavras, Lavras. 
Meylan, B. A.; Probine, M.C. 1969. Microfibril angle as a parameter in timber quality assessment. Forest Prod J 19: 31-34.

Mott, L.; Groom, L.; Shaler, S. 2002. Mechanical properties of individual southern pine fibres. Part II. Comparison of earlywood and latewood fibres with respect to tree height and juvenility. Wood Fibre Sci 34: $221-237$.

Preston, R.D. 1974. The Physical Biology of Plant Cell Walls. Chapman \& Hall, London.

Ramos, L.M.A.; Latorraca, J.V.F.; Pastro, M.S.; Souza, M.T.; Garcia, R.A.; Carvalho, A. M. 2011. Variação radial dos caracteres anatômicos da madeira de Eucalyptus grandis W. Hill Ex Maiden e idade de transição entre lenho juvenil e adulto. Sci For 39: 411-418.

Simpson, W.; Tenwolde, A. 1999. Physical Properties and Moisture Relations of Wood. In: Wood handbook - Wood as an engineering material. Gen. Tech. Rep. FPL- GTR-113. Madison, WI: U.S. Department of Agriculture, Forest Service, Forest Products Laboratory.

Stuart, S. A.; Evans, R. 1995. X-ray diffraction estimation of the microfibril angle variation in Eucalyptus wood. Appita J 48: 197-200.

Waghorn, M. 2006. Effect of initial stand spacing and breed on dynamic modulus of elasticity of Pinus radiata. Ph.D. Thesis, The New Zealand School of Forestry, University of Canterbury.

Wimmer, R.; Downess, G.M.; Evans, R. 2002. Temporal variation of microfibril angle in Eucayptus nitens grown in different irrigation regimes. Tree Physiology 22: 449-457. 